\title{
SWOT Analysis of Religious Tourism in Nong Khai Province, Thailand Proposed Guidelines to Incorporate Temple Stay Program
}

\author{
Thirachaya Maneenetr \\ Director of Center for Asia-Pacific Tourism Research, Faculty of Management Science, Khon Kaen University \\ Email: thirachaya@kku.ac.th \\ Thanh Ha Tran \\ Student in Master Degree of Tourism Management, Faculty of Management Science, Khon Kaen University \\ Email: cholly.pen@gmail.com
}

\section{Doi:10.5901/mjss.2014.v5n23p696}

\begin{abstract}
The aim of this paper is to identify the strengths, weaknesses, opportunities and threats of religious tourism in Nong Khai province, Thailand to incorporate Temple Stay Program, which is a valuable form of religious tourism. Temple Stay Program is a successful Buddhist tourism program in Korea which creatively attracts many tourists throughout the Korean Buddhist culture. A semi-structured interview was applied to collect data from key informants. The results show that religious tourism in Nong Khai province has the potential to incorporate a Temple Stay Program as a core religious tourism product to introduce Thai Buddhist culture. In order to improve the potential for religious tourism in Nong Khai province to establish a Temple Stay Program, the necessary things that should be focused on are 1) diversity of religious activities for tourists 2) improving human resources in tourism 3) arranging public service vehicles to go to temples 4) extensive public relations 5) collaboration by stakeholders.
\end{abstract}

Keywords: strengths, weaknesses, opportunities, religious tourism, Temple Stay Program

\section{Introduction}

Religious tourism is a type of tourism in which participants are motivated either in part or exclusively for religious reasons (Rinschede, 1992). There are several religious reasons for travelling. People encourage or require travel for salvation or spiritual enlightenment (Timothy, 2011). It can be said that religious tourism incorporates visitors and religious sites with faith spiritual and values (Raj \& Morpeth, 2007).

Nowadays, tourism to religious sites is growing worldwide (Hughes et al., 2013) with a lot of motivation for travelling. Many tourists not only travel for their beliefs or spiritual values but also for recreational, educational and cultural purposes (Woodward, 2004).

Travelling with aims to improve ties with Buddhism is an important motivation in Asia. These destinations comprise many countries such as Korea, China, Vietnam, Thailand, etc. where Buddhism is one of the major religions. Tourist activities in the Buddhist religion are diverse and different depending on the social and cultural contexts of each country. However, Buddhist tourism in Korea is noted prominently for its Temple Stay Program which refers to a comprehensive religious and cultural program initiated by the Korean government and Korean religious organizations in 2002 (Wang, 2011). Temple Stay program is a truly unique and special type of accommodation that offers the opportunities for tourists to stay overnight in a Buddhist temple and creatively experience Korean culture (OECD, 2009).

This innovative and successful program for religious tourism in Korea raises the question why religious tourism in Thailand should not adopt and adapt Temple Stay Program to support and enhance Buddhist culture in terms of Thainess.

The researchers focused on Nong Khai province - a border city which is comprised of diversity of culture and social ethnicities such as Vietnamese, Laotian and Thai. The Nong Khai province is a potential destination with natural and cultural sites, religious temples, beautiful cultural landscapes and stunning natural phenomena namely the Naga fireball. Based on tourism resources, especially in Buddhist culture, a question is raised as to whether religious tourism in Nong Khai province can improve its potential to incorporate Temple Stay Program. 


\section{Objectives of the Study}

To study the strengths, weaknesses, opportunities and threats of religious tourism in Nong Khai province

\section{Literature Review}

\subsection{Tourism Destinations}

Destinations are places where people travel and stay for a while to experience certain features or attractions (Leiper, 1995). They include tourism products such as support services and attractions and other tourist resources, basic elements which attract tourists and satisfy their demand on arrival. There are attractions, public and private amenities, accessibility, human resources, image and character and price (UNWTO, 2007). This is consistent with what Buhalis (2000) suggests, that most destinations are comprised of a core of the following six components and referred to as the framework, which includes attractions, accessibility, amenities, available packages, activities and ancillary services. This framework is the amalgam of tourism products, offering an integrated experience to tourists.

Destination is the pull factor to enhance tourism development, because it brings all element components together in a unique image to communicate and fascinate tourists. On the other hand, destination gives a sense of place which exists in both outsiders' perceptions (tourists) and residents' feelings (local people) (European Travel Commission \& World Tourism Organization, 2009) which is the center of the felt value and repository of meaning (Hopkins, 1998).

\subsection{Push and pull factors in tourism}

Push and pull factors provide useful awareness of tourists' motivation and behavior in travelling (Kim at al., 2003) Push factors tend to motivate and create a desire to travel (Crompton, 1979). These are psychological needs which play a significant role in causing a person to feel a disequilibrium that can be corrected through a tourism experience (Dann, 1977; Kim \& Lee, 2002). Iso-Aloha (1982) suggested that the two basic motivational dimensions of travel for leisure are escaping and seeking while Ryan (1991) explained that motivation factors explain why tourists take a trip and what type of experience, destination or activities they want. Therefore, push factors seem to be an internal force which represents the benefits sought by the tourists for going on a holiday or engaging in alternative activities (Zoltan \& Masiero, 2012).

Pull factors, on the other hand, are in contrast with push factors. Pull factors relate to attractions or attributes of the destination itself (Kim at al., 2003; Zoltan \& Masiero, 2012), which can lead an individual tourist to select one destination over another once tourism decisions have been made (Zhou, 2005). Tourism resources are normally considered pull factors such as natural attractions, cultural resources, recreation activities, special events or festivals, and so on (Kim \& Lee, 2002).

Therefore, in terms of logic and time, push factors are antecedents of pull factors (Zoltan \& Masiero, 2012). This is consistent with what Dann (1981) noted, that "once the trip has been decided upon, where to go, what to see or what to do can then be tackled". In conclusion, attractions or tourism resources of destinations have significant impact on the tourists' decision making process. Thus, creating and improving tourism destinations should be considered in tourism management.

\subsection{What is Temple Stay?}

Temple Stay is a temporary stay at temples. It is offered to outside practitioners during their pilgrimage and to Buddhists who seek a temporary retreat for religious practice. Tourists are also welcomed at Temple Stays, nowadays. This seems to be a normal phenomenon in Asian countries such as China, Thailand, Laos, Korea, Japan and India where Buddhism is one of the major religions (Wang, 2010). However, some of these countries do not organize Temple Stay officially. This makes Korea prominent when mentioning Temple Stay Program. In Korea, Temple Stay Program is defined slightly differently from Temple Stay. Temple Stay Program is a unique cultural program designed to let guests from all over the world experience the life of Buddhist practitioners at traditional temples which preserve the 1,700 year old history of Korean Buddhism and culture (Kaplan, 2010). Temple Stay Program not only provides for tourists to attend religious activities such as ceremonies chanting, meditation, tea ceremonies, and communal Buddhist meal service, but also gives them opportunities to experience Korean cultural activities such as making traditional rice cakes, making natural soap in traditional methods, making lotus lanterns or others local handicrafts (OECD, 2009).

Temple Stay Program is comprised of pull factors such as Korean culture, Korean Buddhism, temple destinations and beautiful landscapes for tourists who are Buddhist tourists and non-Buddhist tourists through meaningful activities. Research about international tourists' behaviors regarding Temple Stay Program in a sample of 360 tourists points out 
that Buddhists who participate in this program are only $6.1 \%$, while non- Buddhists or other religions interested in Temple Stay Program are $93.9 \%$. Of tourists that attended this program $55.8 \%$ said they attended to experience Korean traditional culture as their main motivation. More than $79 \%$ of tourists think that the program has high potential to be developed as a cultural tourism resource (OECD, 2009).

In conclusion, the core of Temple Stay Program in Korea involves preserving Buddhist culture and promoting Korean culture. Monks emphasize their roles in teaching and take into account communicating Buddhist Dharma. This may create a connection between the monastery, Buddhists and visitors. On the other hand, Temple Stay Program creates a new brand culture that is different and innovative. It is a successful and valuable case study for countries which creatively promote religious tourism.

\section{Methodology}

\subsection{Research area}

The Nong Khai province is located in the Northeast of Thailand, which is a border city across from Vientiane, Lao's capital. This province is known for the Naga Fireball, a stunning natural phenomenon dealing with beliefs in the Buddhist religion of local people who live in the Mekong region. Nong Khai is comprised of many temples with ancient, wonderful landscapes and historical culture for those who respect and pay homage to the Buddhist religion.

\subsection{Participants}

The key informants were ten participants. There were monks, involved government organizations, tourism entrepreneurs and local philosophers who were involved with temple destination and religious tourism in Nong Khai province.

\subsection{Tool}

Semi-structured interviews were applied to collect data from key informants. Content analysis was used to identify data elements and a matrix table was used to analyze the qualitative data.

\section{Results and Discussion}

\subsection{Potential of religious tourism in Nong Khai province}

Semi-structured interviews with monks, involved government organizations, tourism entrepreneurs and local philosophers provided input on the potential of religious tourism in Nong Khai province, at present. The researchers divided the potential of religious tourism into five aspects which are also pull factors, as shown below:

(1) Attractions: Nong Khai province has a number of Buddhist temples which accounts for $95 \%$ of religious sites (NongKhai Provincial Office, 2011). Temples in Nong Khai province seem to be the center of the beliefs and faith of Buddhists. The well-known temples such as Pho Chai temple, Muang district, Sri Chom Phu Ongtu temple, Thabo district, Nong Khai province have had an astonishing history with the nearby communities for a hundred years (Piewdang at al., 2013). Nice landscapes and fresh atmosphere also attract tourists to visit. It is consistent with Francis et al. (2008) who stated that religious sites are important tourist attractions, and it is the uniqueness and competitiveness of the tourism destinations which fascinate an increasing number of tourists.

(2) Activities: Activities (events and festivals) as motivation in tourism (Csapo, 2012), allows tourists to deepen their experience of a destination and gain respect for cultural differences (Richard, 2009). Tourists can better understand local culture through attending tourism activities. Nong Khai province has many activities and festivals related to the Buddhist religion and local wisdom such as Loy Krathong festival, SongKran festival, and the worship of Buddha at ceremonies. Prominently, Naga Fireballs, allegedly shot from the Mekong River in northwestern Thailand by a mythical serpent known as Naga, also recently became the focus of a major festival that attracts many (mainly domestic) tourist pilgrims (Cohen, 2007). Supporting local festivals in tourism activities will be an instrument for promoting tourism and boosting the regional economy (Felsenstein \& Fleischer, 2003).

(3) Accommodations: Accommodations are an essential element, which is integrally related to the attraction of a destination and enhances its image (Middleton, 1994; Bresler, 2008). At present, Nong Khai province has a 
range of hotels from small to medium size to facilitate all tourists. Temporary stays in temples are also organized for either tourists or Buddhist practitioners.

(4) Accessibility: It is convenient to travel to Nong Khai province, especially by car or public bus, because of the good condition of the roads. For free independent travelers (FIT), it is not easy to reach temple destinations or religious sites because public vehicles are not arranged to go to attractions directly. However, they can rent cars or minibuses with reasonable rates through tour operators or travel agencies. The accessibility issue shows that a destination should be accessible to a large population base via road, train or air, because it will help tourists to be able to travel with relative ease within the destination (UNWTO, 2007).

(5) Safety and Security: Safety and security has been identified as one of the five global forces that will drive the tourism industry in the new millennium (Chiang, 2000). Nong Khai province has public and private hospitality services readily available. This province also has enough security for tourists because Modern Maturity magazine rated Nong Khai as one of the most livable cities for older people.

\subsection{SWOT analysis of religious tourism in Nong Khai province}

SWOT analysis of religious tourism was utilized to point out weaknesses that should be improved and opportunities to support religious tourism in Nong Khai province to incorporate Temple Stay Program, as shown in table 1.

(1)The weaknesses can be defined in two aspects, as shown below:

Human resources in tourism: Tourism staffs with foreign language skills are limited. Moreover, people, especially Monks, who are related to religious tourism, do not explicitly play roles in supporting tourism at religious sites.

Public relations: Public relations are a crucial promotional activity in tourism. It is necessary to create image, share experiences and establish relationships with tourists (Huertas, 2008). But, at present, religious tourism in Nong Khai province faces problems in public relations activities. There are no official public relations on tourism for religious activities and no network connections to promote religious tourism within the province.

(2) The opportunities can also be defined in three aspects as shown below:

Advantages of location: The Nong Khai province is a border province across from Vientiane - Lao's capital. The first friendship bridge Thai - Lao was built to transfer tourists between the two borders. This is an advantage in supporting tourism in the Nong Khai province. Moreover, in 2015, joining in the ASEAN Economic Community should have a positive impact on regional tourism, and travelling by road via border provinces and will be a convenient option for tourists.

Diversity of cultures: Nowadays, Nong Khai province has three main ethnicities Thai, Laotian and Vietnamese. This creates diversity of culture in society and establishes this border province's very unique culture. As Gelbman \& Timonthy (2011) state, a complex reality of living between two societies and cultures makes border areas become important attractions for tourists.

Image of the most livable city: Nong Khai province was ranked $7^{\text {th }}$ in the world as the most livable place. This is a good destination image to communicate to tourists and enhance their feelings of credibility and security.

Table 1. SWOT analysis of religious tourism in Nong Khai province

\begin{tabular}{ll}
\hline Strengths & Weaknesses \\
\hline - A lot of temple destinations & - Lack of tourism staff with foreign language skills \\
- Lots of famous Monks & - No visitor management \\
- Amazing natural phenomenon - Naga fireball & - Religious tourism activities lack variety \\
- Wonderful cultural landscapes & - No network connection among temples in provinces \\
- Famous local traditional festivals & - Lack of ongoing promotion of religious tourism \\
- Diversity of accommodations such as Home Stay and Temporary Stay in temples & - Lack of extensive development of advertising \\
- The faith and beliefs of Buddhists strongly take into account Buddhist religion & - Lack of public service vehicles for access to temple destinations \\
- Lots of festival days involving Buddhist religion & - No established relationships between young people with \\
- Valuable tourist destinations & problems regarding Buddhism \\
- High security in the area & Threats \\
\hline Opportunities & - Natural disasters (floods, typhoons) \\
\hline - Border province between Thai - Lao & - Government conflict \\
- Cooperation among the countries in the Great Mekong Sub region (GMS) & - The lack of support in maintaining of the infrastructure to facilitate \\
- Diversity of social culture in Nong Khai province & tourists \\
- Local communities have a positive attitude towards tourism development & - Length of stay of most tourists only 1-2 days \\
- Development of tourism via Thainess in National Agenda & - Competition from regional tourism \\
- Joining ASEAN Economic Community in 2015 will support regional tourism & - High cost of fuel prices \\
- Trend of tourism to cultural and religious sites & tourism \\
- Nong Khai is one of the most livable provinces in the world (ranking from Modern & - Funding is not supported by the government to integrate religious \\
\hline Maturity magazine ) &
\end{tabular}




\subsection{Improving the potential of religious tourism to incorporate Temple Stay Program}

Temple Stay Program in Korea is a cultural and Buddhist mixed program to promote Korean tourism. Temple Stay Program induces tourism promotion and systematical maintenance construction, diversifies activities in different temples and integrates religious practices. Based on cultural resources, Temple Stay Program exerts a pull motivation on tourists and brings them more new cultural experiences than regular tourism products during participation in this program (Wang, 2011).

Moreover, temples are becoming inclusive heritage centers where monks turn into tour guides and curators of an eclectic, traditional authentic Koreaness (Kaplan, 2010). Lastly, support from the government and nationwide religious organizations are an important factor to success (Wang, 2011). These are the core of Temple Stay Program in Korea.

Nong Khai province has the attributes of a religious tourism destination and has the potential for extensive growth and development. Temple Stay Program is a hopeful form of tourism development based on culture and Buddhism, particularly in Nong Khai and generally in Thailand. As Egreri (2012) states religion is a motivation for people who travel with either spiritual values or cultural values. Supporting tourism to religious sites not only provides new experiences for tourists (especially international tourists) through interacting with local society but also improves the quality of local living through economic benefits (Rotherham, 2007). There seem to be both push and pull factors in the tourist travel process to religious sites.

Therefore, to incorporate Temple Stay Program in Nong Khai province, strategic management plans should be drawn up to administrate, control and evaluate the processes and this is a long term plan for a step by step development.

Crompton (1979) pointed out that tourists are usually motivated by the match of a destination's major attributes to the travelers' needs. In terms of religious tourism, Buddhist temples should be developed by using promotional strategies designed to increase the number of tourists by presenting Buddhist temples as desirable attractions (Choe et al., 2009).

Therefore, the necessary things for the pull strategy to attract tourists which should be focused on for improving the potential of religious tourism in the Nong Khai province are proposed, as shown below:

1) Diversity of religious activities for tourists: Most local festivals reflect Buddhist beliefs. Therefore, religious activities should not only emphasize Buddhist practices in chanting, prayers or ceremonies, but also describe how local festivals relate to Buddhist spirituality. This allows tourists, especially international tourists, to have meaningful Thai cultural experiences.

2) Improvement of human resources in tourism: Monks play crucial roles in religious tourism in disseminating Buddhist wisdom (either the Dharma view or secular view) to tourists. They help make tourists more familiar with the religion. Foreign language skills are also necessary to facilitate international tourists.

3) Public service vehicles to temples: Providing public service vehicles to temples in peripheral areas is convenient and easy for tourists. It also reduces environmental issues such as global warming.

4) Extensive public relations (Brochures/websites): Brochures on religious activities and temple destinations created by Buddhist or religious organizations. Religious tourism websites should also be established in at least two languages, Thai and English, to reach more international tourists.

5) Collaboration by stakeholders: Collaboration should be established at several levels such as temple-to-temple, temple-to-local community, and temple-to-public and private organizations to create mega networks to support religious tourism.

\section{Conclusion}

Religious tourism in Nong Khai province has the potential for extensive development and Temple Stay Program is a valuable program for religious tourism to incorporate. SWOT analysis of religious tourism in Nong Khai province identified ten strengths, nine weaknesses, eight opportunities and seven threats. The weaknesses that should be improved includes religious tourism management and public relations. There are opportunities to support religious tourism development which include 1) Advantage of location 2) Diversity of cultures 3) Government policy on tourism development.

Temple Stay Program is a long term plan used to achieve a step by step objective. But, the necessary things to focus on to improve religious tourism are defined as 1) Diversity of religious activities for tourists 2) Improvement of human resources in tourism 3) Public service vehicles to temples 4) Extensive public relations (Brochures/websites/) 5) Collaboration by stakeholders. 


\section{References}

Buhalis, D. (2000). Marketing the Competitive destination of the future. Tourism Management, 21, 97-116. http://dx.doi.org/10.1016/ S02615177(99)00095-3.

Chiang, L.C. (2000). Strategies for Safety and Security in Tourism: A conceptual framework for the Singapore Hotel Industry. The Journal of Tourism Studies, 11(2), 44 - 52. Retrieved from http://www.jcu.edu.au/business/public/groups/everyone/ documents/journal_article/jcudev_012729.pdf.

Choe, J., Blazey, M. \& Mitas, O. (2013). Motivations of non-Buddhists visiting Buddhist Temples. Current Issues in Tourism. DOI: 10.1080/13683500.2013.771627.

Cohen, E. (2007). The "Postmodernization" of a Mythical Event: Naga Fireballs on the Mekong River. Tourism Culture \& Communication,7(3),169-181. http://dx.doi.org/10.3727/109830407782212493.

Crompton, J. L. (1979). Motivations for pleasure vacation. Annals of Tourism Research, 6(4), 408-424. http://dx.doi.org/10.1016/01607383(79)90004-5

Csapo, J. (2012). The Role and Importance of Cultural Tourism in Modern Tourism Industry, Strategies for Tourism Industry - Micro and Macro Perspectives, M. Kasimoglu (Ed.), ISBN: 978-953-51-0566-4, InTech, DOI: 10.5772/38693. Available from: http://www.intechopen.com/books/strategies-for-tourism-industry-micro-and-macro-perspectives/the-role-and-importance-of-culturaltourism-in-modern-tourism-industryDann, G.M.S. (1977). Anomie, ago-enhancement and tourism. Annals of Tourism Research, 4 (4), 184-194. http://dx.doi.org/10.1016/0160-7383(77)90037-8.

Egreri, I. (2012). Tourism at Religious Sites: A Case from Mardin, Turkey. Geographica Timisiensis, 21(1), 5-15. http://www.geografie.uvt.ro/old/cercetare/publicatii/geographica/abstracte/Geographica2012-1/ARTICOL_1_EGRESI.pdf.

European Travel Commission and World Tourism Organization. (2009). Handbook on Tourism Destination Branding. Madrid: World Tourism Organization.

Felsenstein, D. \& Fleischer, A. (2003). Local festivals and Tourism Promotion: The Role of Public Assistance and Visitor Expenditure. Journal of Travel Research, 41, 385 - 391. DOI: 10.1177/0047287503251548.

Francis, L.J., Williams, E., Annis, J., \& Robbins, M. (2008). Understanding cathedral visitors: psychological type and individual differences in experience and appreciation. Tourism Analysis, 13 (1), 71-80. http://dx.doi.org/10.3727/108354208784548760

Gelbman, A. \& Timonthy, D.J. (2011). Border complexity, tourism and international exclaves: A case study. Annals of Tourism Research, 38(1), 110 - 131. http://dx.doi.org/10.1016/j.annals.2010.06.002.

Huertas, A. (2008). Public relations and tourism: Fighting for the role of public relations in tourism. Public Relations Review, $34(4), 406-408$. http://dx.doi.org/10.1016/j.pubrev.2008.07.001.

Hopkins, J. (1998). Commodifying the countryside: marketing myths of rurality. In R., Butler, C.M. Hall \& J. Jenkins (Eds.). Tourism and recreation in rural area, pp. 139-156. UK: Jonh Wiley \& Sons Inc.

Hughes, K., Bond, N. \& Ballantyne, R. (2013). Designing and managing interpretive experience at religious sites: Visitors' perception of Canterbury Cathedral. Tourism Management 36, 210 - 220. http://dx.doi.org/10.1016/j.tourman.2012.11.022.

Iso-Aloha, S.E. (1982). Towards a social psychological theory of tourism motivation: A rejoinder. Annals of Tourism Research, 9(2), $256-262$. http://dx.doi.org/10.1016/0160-7383(82)90049-4.

Kim, S.S., Lee, C. \& Klenosky, D.B.(2003). The influence of push and pull factors at Korean national parks. Tourism Management, 24, $169-180$. http://dx.doi.org/10.1016/S0261-5177(02)00059-6

Kim, S. \& Lee, C. (2002). Push and pull relationships. Annals of Tourism Research 29(1), 257-260. http://dx.doi.org/10.1016/S0160-7383(01)00043-3.

Leiper, N. (1995). Tourism management. Melbourne: RMIT Press.

Kaplan, U. (2010). Images of Monasticism: The Temple Stay Program and the Re-branding of Korean Buddhist Temples. Korean Studies, 34,127 - 146. DOI: $10.1353 / \mathrm{ks} .2010 .0010$

Middleton, V.T.C. (1994). Marketing in travel and tourism. Second editon. UK: Butterworth-Heimann Ltd.

NongKhai Provincial Office. (2011). Basic Information of Nong Khai province. Retrieved from http://123.242.162.3/nongkhai/files/ 714034641doc24-06-54.docOECD. (2009). Chapter 8: Temple Stay Programme, Korea". The Impact of Culture on Tourism, OECD, Paris, pp 115 - 127. Retrieved from http://www.oecd.org/korea/42040158.pdf

Piewdang, S., Mekkamol, P. \& Untachai, S. (2013). Measuring Spiritual Tourism Management in Community : A Case Study of Sri Chom Phu Ongtu Temple, Thabo district, Nongkhai province,Thailand. Procedia - Social and Behavioral Sciences, 88, 96 - 107. http://dx.doi.org/10.1016/j.sbspro.2013.08.485.

Raj, R. \& Morpeth, N.D. (2007). Religious tourism and pilgrimage festivals management: An international perspective. Wallingford, Oxfordshire: CABI Publishing.Richards, G. (2009). Tourism development trajectories - From culture to creativity? Tourism Research and Marketing, Barcelona. Paper presented to the Asia-Pacific Creativity Forum on Culture and Tourism, Jeju Island, Republic of Korea, 3-5 June 2009. http://www.tram-research.com/atlas/APC\%20Paper\%20Greg\%20Richards.PDF

Rinschede, G. (1992). Form of religious tourism. Annals of Tourism Research, 19(1), 51 - 67. http://dx.doi.org/10.1016/0160-7383(92)90106-Y.

Rotherham, I.D. (2007). Sustaining Tourism Infrastructures for Religious Tourists and Pilgrims within the UK. In R. Raj \& N.D. Morpet (Eds). Religious Tourism and Pilgrimage Festivals. Wallingford, Oxfordshire: CABI Publishing. pp 64 -77.

Ryan, C. (1991). Recreational Tourism: A Social Science perspective. London: Routledge.

Timothy, D.J. (2011). Cultural Heritage and Tourism: An Introduction. Bristol ; Buffalo : Channel View Publications.

Wang, W. (2011). Explore the Phenomenon of Buddhist Temple Stay in South Korea for Tourists. UNLV Theses/Dissertations/Professional Papers/Capstone.Paper 1074. Retrieve from http://digitalscholarship.unlv.edu/theses dissertations/1074.

Woodward, S.C. (2004). Faith and tourism: planning tourism in relation to places of worship. Tourism and Hospitality Planning \& Development, 1(2), 173 - 186. DOI: 10.1080/1479053042000251089.

World Tourism Organization, (2007). A Practical guide to tourism Destination Management. World Tourism Organization: Madrid.

Zoltan, J. \& Masiero, L. (2012). The relation between push motivation and activity consumption at the destination within the framework of destination card. Journal of Destination Marketing \& Management, 1,84-93. http://dx.doi.org/10.1016/j.jdmm.2012.09.002. 